\title{
PEMANFAATAN TANIN DARI KULIT KAYU TINGI (Ceriops tagal) SEBAGAI BAHAN PENYAMAK NABATI: PENGARUH PENAMBAHAN ALUM DAN MIMOSA
}

\section{UTILIZATION OF TINGI (Ceriops tagal) BARK'S EXTRACT AS VEGETABLE TANNING MATERIAL: THE INFLUENCE OF ALUM AND MIMOSA ADDITION}

\author{
Emiliana Kasmudjiastuti*, Sri Sutyasmi, Titik Purwati Widowati \\ Balai Besar Kulit, Karet dan Plastik, Jl. Sokonandi No. 9 Yogyakarta 55166, Indonesia \\ *Penulis korespondensi.Telp.: +62 274 512929, 563939, Fax.: + 62274563655 \\ E-mail: emil_bbkkp@yahoo.com
}

Diterima: 13 Maret 2015 Direvisi: 24 Mei 2015 Disetujui: 1 Juni 2015

\begin{abstract}
This research aimed at determining the effectiveness of the Tingi bark's extract as vegetable tanning material and the optimum formulations of Tingi extract for lining leather tanning, when combined with alum and mimosa. The research variables included the solution compositions of alum, Tingi extract, and mimosa, as well as the process sequences in which the hides were exposed to each aforementioned solution. There were 8 (eight) different treatments performed in this research; those are alum (4\%)-Tingi, alum (6\%)-Tingi, alum (4\%)-Tingi-mimosa (5\%), alum (6\%)-Tingi-mimosa (5\%), Tingi-alum (4\%), Tingi-alum (6\%), Tingi-mimosa (5\%)-alum (4\%), and Tingimimosa (5\%)-alum (6\%). Characterization methods included chemical and physical tests. The results show that the Tingi extract can be used as vegetable tanning material, and the optimum properties were obtained when the alum (4\%) was added after the Tingi extract \{Tingi-alum (4\%)\}.The optimum properties were shrinkage temperature of $86^{\circ} \mathrm{C}$; total ash content of $0.73 \%$; water soluble matter of $0.89 \%$; pH of 3.78; degree of tannage of $96.37 \%$; tensile strength of $370.65 \mathrm{~kg} / \mathrm{cm}^{2}$; elongation at break of $36.52 \%$; rubfastness of 5 (dry); and 4 (wet). The resulting leather also meet the requirements of Ethiopian Standard 1185:2005, Leather-Lining leather-Specification.
\end{abstract}

Keywords: Tingi bark's extract, alum, mimosa, vegetable tanning, lining leather.

\begin{abstract}
ABSTRAK
Penelitian ini bertujuan untuk mengetahui efektifitas ekstrak kulit kayu Tingi sebagai bahan penyamak nabati dan formulasi ekstrak Tingi yang optimal pada penyamakan kulit lapis, ketika dikombinasikan dengan alum dan mimosa. Variabel penelitian meliputi komposisi larutan alum, ekstrak Tingi, dan mimosa, serta urutan proses di mana kulit diekspos ke masing-masing larutan tersebut di atas. Terdapat 8 (delapan) perlakuan berbeda dalam penelitian ini, yaitu alum (4\%)-Tingi, alum (6\%)-Tingi, alum (4\%)-Tingi-mimosa (5\%), alum (6\%)-Tingimimosa(5\%), Tingi-alum (4\%), Tingi-alum (6\%), Tingi-mimosa (5\%)-alum (4\%), and Tingi-mimosa-alum (6\%). Metode karakterisasi meliputi pengujian kimia dan fisika. Hasil penelitian menunjukkan bahwa ekstrak Tingi dapat digunakan sebagai bahan penyamak nabati, dan sifat-sifat optimum diperoleh ketika penambahan alum (4\%) dilakukan setelah penambahan ekstrak Tingi \{Tingi-alum (4\%)\}. Sifat-sifat optimum tersebut adalah: suhu kerut $86^{\circ} \mathrm{C}$; kadar abu jumlah 0,73\%; kadar zat larut dalam air 0,89\%; pH 3,78; derajat penyamakan 96,37\%; penyamakan masak; kekuatan tarik 370,65 kg/cm²; kemuluran 36,52\%; ketahanan gosok cat nilai 5 (kering) dan 4 (basah). Kulit yang dihasilkan juga memenuhi persyaratan Ethiopian Standard 1185: 2005, Leather-Lining leather-Specification.
\end{abstract}

Kata kunci : kulit kayu Tingi, alum, mimosa, bahan penyamak nabati, kulit lapis.

\section{PENDAHULUAN}

Bahan penyamak nabati bisa digunakan untuk menyamak (full nabati) atau sebagai bahan penyamakan ulang. Bahan penyamak nabati umumnya diaplikasikan pada light leather seperti shoe upper, lining, glove, garment, handbag, dan lain-lain yang dibuat dari kulit domba, kambing, dan calf. Bahan penyamak nabati yang umum digunakan di 
industri penyamakan kulit adalah mimosa.

Pohon Tingi (Ceriops tagal) termasuk jenis mangrove merupakan salah satu sumber tanin yang sangat potensial (Rusila et al., 2012). Tanin merupakan substansi terpenting yang ada di dalam tumbuhan, terdapat pada bagian kayu, kulit kayu, daun buah dan akar, yang terjadi secara alami (Musa \& Gasmelseed, 2012; Mekonnen et al., 2013; Haroun et al., 2013b) dan dapat digunakan sebagai bahan untuk penyamakan kulit (Vieira et al., 2011; Chupin et al., 2013). Tanin secara ilmiah didefinisikan sebagai senyawa polifenol (Ucar et al., 2013; Haroun et al., 2013a; Bharudin et al., 2014) yang mempunyai berat molekul tinggi (500-3000 Da), terdiri atas elemen C, H, O dengan formula empirik $\mathrm{C}_{76} \mathrm{H}_{52} \mathrm{O}_{46}$ dan mempunyai gugus hidroksil dan gugus lainnya (seperti karboksil) sehingga dapat membentuk ikatan-ikatan hidrogen dengan kolagen dan membuat matrik polyphenolic tanning dan makromolekul lainnya di bawah kondisi lingkungan tertentu (Danarto dkk., 2011; Duki et al., 2013).

Menurut Kasmudjiastuti (2014), tanin kulit kayu Tingi memiliki daya astrigency (daya samak) yang baik. Selain itu, data spektrum FTIR tanin Tingi menunjukkan adanya gugus hidroksil (vO-H; vN-H) pada area 3467,42-3057,03 $\mathrm{cm}^{-1}$, gugus aromatik $(\mathrm{rC}-\mathrm{H})$ pada area $2875-733 \mathrm{~cm}^{-1}$, $\mathrm{VC}=\mathrm{O}$ (ester group in tanned material) pada area $174744-1612,42 \mathrm{~cm}^{-1}, \mathrm{v}-\mathrm{OH}$; R-COO- pada area $1444,63 \mathrm{~cm}^{-1}$ dan $\mathrm{r}\left(\mathrm{SO}_{4}\right)^{2-}, \mathrm{R}-\mathrm{SO}_{3}, \mathrm{R}-\mathrm{SO}_{3} \mathrm{H}$ pada area $1112,82-1062.73 \mathrm{~cm}^{-1}$ yang serupa dengan Mimosa sehingga dapat digunakan sebagai alternatif bahan penyamak nabati.

Prinsip proses penyamakan nabati adalah menggunakan zat penyamak nabati dengan molekul kecil dan daya ikat yang kecil sehingga penetrasi zat penyamak cepat dan kulit yang dihasilkan tidak mengalami kontraksi. Molekul dan daya ikatnya kemudian diperbesar dengan cara mengubah kepekatan dan $\mathrm{pH}$ sehingga kulit menjadi tersamak dengan rata. Berdasarkan sifat-sifat tersebut, maka penyamakan kulit dengan bahan penyamak nabati dimulai dengan zat penyamak yang mempunyai kepekatan rendah, $\mathrm{pH}$ tinggi, dan berangsur-angsur kepekatan zat penyamak dinaikkan dan diakhiri dengan zat penyamak kepekatan tinggi, dan $\mathrm{pH}$ rendah. Mekanisme penyamakan nabati adalah pembentukan jumlah ikatan hidrogen antara beberapa gugus hidroksil fenol dari tanin dan atom oksigen dan nitrogen dalam kolagen. Stabilitas hidrotermal relatif rendah karena ikatan hidrogen rendah (Musa et al., 2011).

Kulit yang disamak menggunakan bahan penyamak nabati mempunyai beberapa kelemahan, salah satu diantaranya adalah kestabilan terhadap panas (hydrothermal stability) rendah karena ikatan silang dengan jaringan kolagen tidak cukup kuat. Oleh karena itu dalam penyamakan nabati perlu kombinasi bahan penyamak, seperti vegetable-oxozolidine, vegetable-zinc, vegetablealuminium. (Musa et al., 2011). Kombinasi penyamakan menggunakan metal dan bahan penyamak nabati memainkan peranan penting terkait dengan kestabilan hidrotermal (Duki et al., 2013; Ali et al., 2013b).

Penggunaan aluminium pada penyamakan nabati memainkan peranan penting dalam pembentukan ikatan dan stabilitas yang komplek serta menaikkan stabilitas hidrotermal (Musa et al., 2011). Suhu kerut yang tinggi menunjukkan derajat ikat silang dan stabilitas hidrotermal yang tinggi. Penggunaan tanin Tingi secara tunggal, kulit yang dihasilkan cenderung harsh, thickgrained, penetrasinya lambat, sehingga dalam penggunaannya perlu dicampur dengan tanin dari wattle (Mimosa) atau Quebracho (Roberts \& Etherington, 1982). Oleh karena itu dalam penelitian ini perlu dipelajari efek penambahan alum pada pretanning (sebelum penyamakan) dan retanning (setelah penyamakan), serta pengaruh penambahan mimosa.

Tujuan penelitian untuk mengetahui efektivitas tanin dari larutan ekstrak kulit kayu Tingi sebagai bahan penyamak nabati dengan penambahan alum sebagai ikatan silang (crosslinking) untuk menaikkan stabilitas hidrotermal dan untuk mengetahui formula yang optimal pada penyamakan kulit lapis.

\section{BAHAN DAN METODE Bahan Penelitian}

Bahan penelitian terdiri atas bahan baku dan bahan-bahan untuk penyamakan kulit. Bahan baku berupa kulit kambing pikel dari penyamak kulit di Yogyakarta. Kulit kayu Tingi berasal dari distributor kulit kayu Tingi di Ngasem Yogyakarta (asal kulit kayu dari Sulawesi selatan). Puder Mimosa berasal dari Cekoslovakia (produk impor/paten). Bahan lain seperti phenolic syntan, acrylic syntan, melamin resin, alum (tawas), minyak sintetis, minyak kationik, asam formiat, dan sodium bicarbonate berasal dari distributor bahan kimia untuk kulit di Yogyakarta. 


\section{Peralatan Penelitian}

Alat yang digunakan dalam penelitian ini meliputi alat untuk proses dan alat untuk pengujian. Alat untuk proses terdiri atas Crusher, Baume meter, termometer, drum penyamakan, dan alat pentang (toggle). Alat untuk pengujian terdiri atas Crockmeter merek AATCC model M238 AA, tensile strength tester merk Zwick Roell ZO20 tipe KAP-TC, dan Scanning Electron Microscope (SEM) merk Jeoul JSM-6360LA.

\section{Metode Penelitian}

\section{Pembuatan larutan ekstrak}

Kulit kayu Tingi (Ceriops tagal) dengan ukuran $5 \mathrm{~cm} \times 2 \mathrm{~cm} \times 5 \mathrm{~mm}$ dengan berat $5 \mathrm{~kg}$ dikecilkan dimensinya menggunakan mesin crusher

Tabel 1. Matriks penelitian.

\begin{tabular}{|c|c|c|}
\hline No. & $\begin{array}{c}\text { Variabel } \\
\text { penelitian }\end{array}$ & $\begin{array}{c}\text { Kode dalam } \\
\text { penelitian }\end{array}$ \\
\hline 1. & Alum (4\%) - Tingi & A4T \\
\hline 2. & Alum $(6 \%)$ - Tingi & A6T \\
\hline 3. & $\begin{array}{l}\text { Alum (4\%) - Tingi - } \\
\text { mimosa }\end{array}$ & A4TM \\
\hline 4. & $\begin{array}{l}\text { Alum }(6 \%) \text { - Tingi - } \\
\text { mimosa }\end{array}$ & A6TM \\
\hline 5. & Tingi - alum (4\%) & TA4 \\
\hline 6. & Tingi - alum $(6 \%)$ & TA6 \\
\hline 7. & $\begin{array}{l}\text { Tingi - mimosa - } \\
\text { alum }(4 \%)\end{array}$ & TMA4 \\
\hline 8. & $\begin{array}{l}\text { Tingi - mimosa - } \\
\text { alum }(6 \%)\end{array}$ & TMA6 \\
\hline 9. & Tingi & Kontrol \\
\hline
\end{tabular}

sehingga berdimensi panjang $16,7 \mathrm{~mm} \times 14,7 \mathrm{~mm}$ x $1,8 \mathrm{~mm}$. Kulit kayu Tingi mengandung kadar tanin sebesar 11,46\% dan kadar non tanin 1,30\% (Kasmudjiastuti, 2014). Kulit kayu Tingi tersebut dikeringkan di udara terbuka dan diekstrak menggunakan sistem counter current, suhu awal pelarut (air) $80^{\circ} \mathrm{C}$, perbandingan berat kulit kayu Tingi dengan pelarut adalah 1:3 dan waktu ekstraksi 24 jam. Ekstraksi dilakukan terhadap 10 $\mathrm{kg}$ kulit kayu Tingi. Hasil ekstraksi berupa cairan berwarna merah kecoklatan dengan tiga tingkatan densitas yaitu $1^{\circ} \mathrm{Be}(10$ liter $), 3^{\circ} \mathrm{Be}$ (5 liter), dan $5^{\circ} \mathrm{Be}$ (5 liter). Kemudian pengujian total ekstrak, total larutan, kadar tanin dan non tanin dilakukan terhadap ketiga larutan ekstrak tersebut sebelum digunakan sebagai bahan penyamakan kulit.

\section{Penyamakan kulit}

Variabel dalam penelitian ini adalah konsentrasi alum (4 dan 6\%), penggunaan mimosa (dengan atau tanpa mimosa), serta urutan penambahan alum dalam proses penyamakan kulit (sebelum atau sesudah penambahan penyamak nabati). Adapun pengaruh dari variabel-variabel tersebut di atas diteliti secara sistematis dengan variasi yang dapat dilihat pada Tabel 1. Pemakaian ekstrak Tingi dalam larutan $\left(200 \% 1^{\circ} \mathrm{Be}, 150 \% 3^{\circ} \mathrm{Be}\right.$ dan $100 \% 5^{\circ} \mathrm{Be}$ ), puder mimosa dalam larutan (5\%) dibuat tetap dan sebagai kontrol, hanya digunakan Tingi saja.

Formulasi dan kondisi operasi penyamakan kulit lapis dalam penelitian ini disajikan pada Tabel 2 dan 3, sedangkan formulasi dan kondisi operasi yang dikenakan pada kulit setelah proses

Tabel 2. Formulasi penyamakan alum-tingi/ alum-tingi-mimosa dari kulit pikel kambing.

\begin{tabular}{llccc}
\hline Proses & Bahan kimia/alat & $\%$ & $\mathrm{pH}$ & Durasi (menit) \\
\hline Pre-tanning & Air pikel & 100 & $2,8-3,0$ & 60 \\
& Alum (variasi) & $(4,6)$ & & 40 \\
& Minyak kationik & 1 & & \\
Pengaturan pH & Sodium bikarbonat & 0,75 & $4,5-4,7$ & $(3 \times 15)+30$ \\
& & & & 30 \\
Tanning & Phenolic syntan & 2 & & $90, \mathrm{ON}$ \\
& Tingi $(1 \circ \mathrm{Be})$ & 200 & & 90 \\
& Tingi $(3 \circ \mathrm{Be})$ & 150 & & 60 \\
& Tingi $(5 \circ \mathrm{Be})$ & 100 & & $3 \times 10+30$ \\
Fixing & Mimosa & 5 & & \\
Drain, ON, Shaving & Asam formiat & 0,5 & 3,5 & \\
\hline
\end{tabular}


Tabel 3. Formulasi penyamakan tingi-alum/tingi-mimosa-alum dari kulit pikel kambing.

\begin{tabular}{llccc}
\hline Proses & Bahan kimia & $\%$ & $\mathrm{pH}$ & Durasi (menit) \\
\hline Pengaturan $\mathrm{pH}$ & a. Air & 1000,75 & & \\
& b. Sodium bikarbonat & 1 & $4,5-4,7$ & \\
& c. Minyak kationik & & & $(3 \times 15)+30$ \\
& & & & 40 \\
Tanning & Phenolic syntan & 2 & & 30 \\
& Tingi $(1 \circ \mathrm{Be})$ & 200 & & $120, \mathrm{ON}$ \\
& Tingi (3 $\circ \mathrm{Be})$ & 150 & & 120 \\
& Tingi $(5 \circ \mathrm{Be})$ & 100 & & 60 \\
& Mimosa & 5 & & 60 \\
Basification & Alum (variasi) & $(4,6)$ & & $3 \times 15+30$ \\
Drain, ON, Shaving & Sodium bikarbonat & 0,75 & 4 & \\
\hline
\end{tabular}

Tabel 4. Formulasi proses setelah penyamakan untuk semua perlakuan.

\begin{tabular}{llccc}
\hline Proses & Bahan kimia & $\%$ & $\mathrm{pH}$ & Durasi (menit) \\
\hline Pencucian & Air & 200 & & 10 \\
Netralisasi & Sodium bikarbonat & 0,75 & $5,0-5,5$ & $3 \times 15+30$ \\
Drain, Pencucian & & & & \\
Pre-retanning & Air & 100 & & 40 \\
& Acrylic syntan & 2 & & 40 \\
Pre-fatliquor & Lipoderm Liq. SAF & 2 & & 30 \\
& Basyntan UR & 4 & & \\
\hline
\end{tabular}

penyamakan, untuk semua variasi perlakuan, disajikan pada Tabel 4.

\section{Pengukuran suhu kerut}

Kulit yang telah disamak dipotong-potong dengan dimensi sekitar 1 x $2 \mathrm{~cm}$ sebagai sampel untuk diukur suhu kerutnya. Data suhu kerut kulit digunakan sebagai parameter untuk menentukan tingkat kemasakan kulit tersamak.

\section{Pengujian sifat kimia dan fisika}

Pengujian secara kimia meliputi uji kadar abu jumlah, kadar zat larut dalam air, $\mathrm{pH}$, dan derajat penyamakan. Pengujian secara fisis meliputi uji penyamakan, kekuatan tarik, kemuluran dan ketahanan gosok cat. Pengujian tersebut di atas didasarkan pada persyaratan mutu kulit lapis menggunakan Ethiopian Standard ES 1185:2005, Leather-Lining Leather Specification, mengingat tahun terbit Standar Nasional Indonesia terlalu lama yaitu tahun 1989 dan syarat-syarat mutu telah disempurnakan.

Analisis Scanning Electron Microscopic (SEM)

Sampel kulit yang telah disamak dianalisis struktur jaringan kulitnya menggunakan Scanning Electron Microscopic (SEM).

\section{HASIL DAN PEMBAHASAN}

\section{Hasil Uji Larutan Ekstrak Kulit Kayu Tingi}

Hasil uji larutan ekstrak kulit kayu Tingi disajikan pada Tabel 5. Dari Tabel 5 dapat diketahui bahwa semakin tinggi konsentrasi larutan ekstrak Tingi maka kadar tanin yang terkandung semakin banyak. Ketiga larutan ekstrak ini akan digunakan dalam proses penyamakan kulit lapis. Seperti telah disebutkan di atas, bahwa penyamakan dilakukan secara bertahap yaitu dengan menggunakan larutan ekstrak dengan konsentrasi paling rendah, sedang dan akhirnya dengan konsentrasi paling tinggi.

\section{Suhu Kerut}

Suhu kerut adalah suhu yang menunjukkan bahwa kulit telah masak dimana struktur molekul kolagen telah stabil. Pada kulit samak nabati, molekul-molekul tanin membentuk beberapa ikat- 
Tabel 5. Hasil uji larutan ekstrak kulit kayu Tingi.

\begin{tabular}{lccc}
\hline Uraian & $\begin{array}{c}\text { Larutan ekstrak } \\
\text { Tingi }(1 \circ \mathrm{Be})\end{array}$ & $\begin{array}{c}\text { Larutan ekstrak Tingi } \\
(3 \circ \mathrm{Be})\end{array}$ & $\begin{array}{c}\text { Larutan ekstrak Tingi } \\
(5 \circ \mathrm{Be})\end{array}$ \\
\hline Total ekstrak, g/l & 21,98 & 74,46 & 82,72 \\
Total larut,g/l & 21,48 & 55,42 & 82,38 \\
Kadar non tanin, g/l & 3,58 & 5,18 & 9,20 \\
Kadar tanin, g/l & 17,90 & 50,24 & 73,18 \\
\hline
\end{tabular}

an hidrogen dengan kolagen dan membuat matriks penyamakan. Suhu kerut (Ts) merupakan salah satu parameter yang paling penting dalam karakteristik stabilitas termal dari kulit, yaitu suhu di mana sampel kulit mulai menyusut dalam air atau media pemanas lainnya (Ali et al., 2013a).

Gambar 1 menunjukkan data suhu kerut sebagai fungsi dari variasi perlakuan dalam penelitian. Dari gambar tersebut dapat dilihat bahwa kisaran suhu kerut adalah $83-90^{\circ} \mathrm{C}$ dan semua perlakuan (A4T, A6T, A4TM, A6TM, TA4, TA6, TMA4, dan TMA6) mencapai suhu kerut di atas suhu kerut perlakuan kontrol $\left(81^{\circ} \mathrm{C}\right)$. Hal ini menunjukkan bahwa penambahan alum dapat menaikkan suhu kerut, sesuai dengan apa yang dinyatakan oleh Musa et al., (2011) bahwa penggunaan aluminium pada penyamakan nabati memainkan peranan penting dalam pembentukan ikatan dan stabilitas yang komplek serta menaikkan stabilitas hidrotermal. Suhu kerut yang tinggi menunjukkan derajat ikat silang dan stabilitas hidrotermal yang tinggi. Suhu kerut tertinggi $\left(90^{\circ} \mathrm{C}\right)$ dicapai oleh perlakuan penyamakan menggunakan larutan ekstrak Tingi yang diawali dengan penambahan alum $4 \%$ (A4T). Suhu kerut terendah $\left(83^{\circ} \mathrm{C}\right)$ dicapai oleh perlakuan penyamakan menggunakan larutan ekstrak Tingi yang diawali dengan penambahan alum 6\% (A6T) dan perlakuan penyamakan menggunakan larutan ekstrak Tingi de-

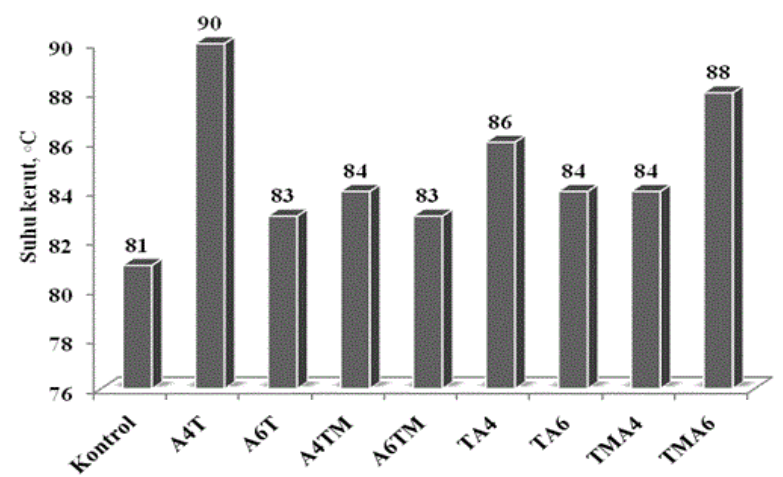

Gambar 1. Grafik histogram suhu kerut. ngan kombinasi mimosa yang diawali dengan penambahan alum 6\% (A6TM). Penggunaan alum $4 \%$ sebagai pre-tanning, tanpa penambahan mimosa (A4T) menunjukkan suhu kerut $\left(90^{\circ} \mathrm{C}\right)$ dan dengan penambahan mimosa (A4TM: $84^{\circ} \mathrm{C}$ ) lebih tinggi dari penggunaan alum 6\% (A6T dan A6TM: $83^{\circ} \mathrm{C}$ ). Penggunaan alum $4 \%$ (TA4 : $86^{\circ} \mathrm{C}$ ) sebagai retanning menunjukkan suhu kerut lebih tinggi dari penggunaan alum $6 \%\left(\mathrm{TA} 6: 84^{\circ} \mathrm{C}\right.$ ). Hal ini menunjukkan bahwa penggunaan alum yang optimal baik untuk pre- tanning (sebelum penyamakan) maupun retanning (setelah penyamakan) adalah $4 \%$. Penambahan mimosa menurut Robert \& Etherington (1982) hanya untuk membantu penetrasi Tingi kedalam jaringan kulit, karena penetrasi tanin Tingi lambat, sehingga dalam penggunaannya perlu dicampur dengan tanin dari Wattle (Mimosa).

\section{Hasil Uji Kimia \\ Kadar abu jumlah}

Kadar abu jumlah kulit tersamak menunjukkan jumlah mineral yang terdapat di dalam kulit tersamak. Beberapa unsur mineral yang terdapat dalam kulit tersamak diantaranya potasium, kalsium, besi, fosfor, klorida, sulfat, dan karbonat (Suparno et al., 2011)

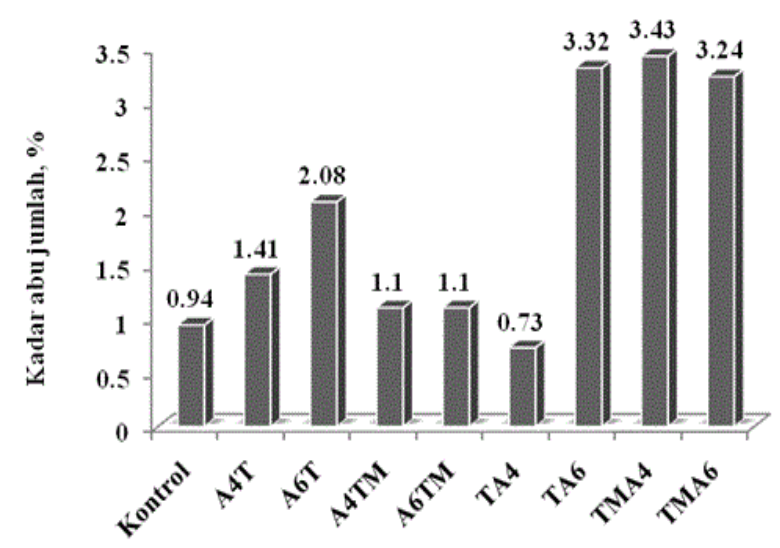

Gambar 2. Grafik histogram kadar abu jumlah kulit tersamak. 
Pada Gambar 2 dapat dilihat bahwa kisaran kadar abu jumlah adalah 0,73-3,43\%. Kadar abu jumlah untuk perlakuan TA4, A4T, A4TM, A6TM dan kontrol memenuhi persyaratan Ethiopian Standard ES 1185: 2005, Leather-Lining leatherSpecification, yang mempersyaratkan maksimum $2 \%$. Sedang untuk perlakuan TA6, TMA4, TMA6 dan A6T tidak memenuhi persyaratan karena $>$ $2 \%$. Hal ini dapat disebabkan karena pada proses pencucian yang kurang sempurna sehingga masih banyak mineral yang menempel pada kulit. Di samping itu karena pada proses pengapuran terjadi pengikatan unsur $\mathrm{Ca}$ dari kapur oleh protein kulit, sehingga apabila proses pembuangan kapur kurang sempurna, maka unsur Ca di dalam kulit masih akan terikat (Nugraha, 1999). Kadar abu jumlah terendah adalah $0,73 \%$ dicapai oleh perlakuan penyamakan menggunakan larutan ekstrak Tingi diikuti dengan alum 4\% (TA4). Kadar abu jumlah tertinggi adalah $3,43 \%$ dicapai oleh perlakuan penyamakan menggunakan larutan ekstrak Tingi dengan kombinasi mimosa dan dikuti penambahan alum 4\% (TMA4). Kadar abu jumlah untuk perlakuan kontrol adalah 0,94\%.

\section{Kadar zat larut dalam air}

Di dalam struktur tenunan serat kulit tersamak terdapat material bahan penyamak baik yang terikat maupun tidak terikat. Derajat kestabilan tanin yang terikat pada kolagen kulit itu bervariasi sehingga ada sebagian tanin yang sudah terikat pada kolagen masih dapat terlarut oleh air $(\mathrm{Nu}-$ graha, 1999).

Pada Gambar 3 dapat dilihat bahwa kadar zat larut dalam air tertinggi adalah 3,1\% dicapai oleh perlakuan penyamakan menggunakan larutan ekstrak Tingi diikuti dengan penambahan Alum $6 \%$ (TA6). Sedangkan kadar zat larut dalam air teren-

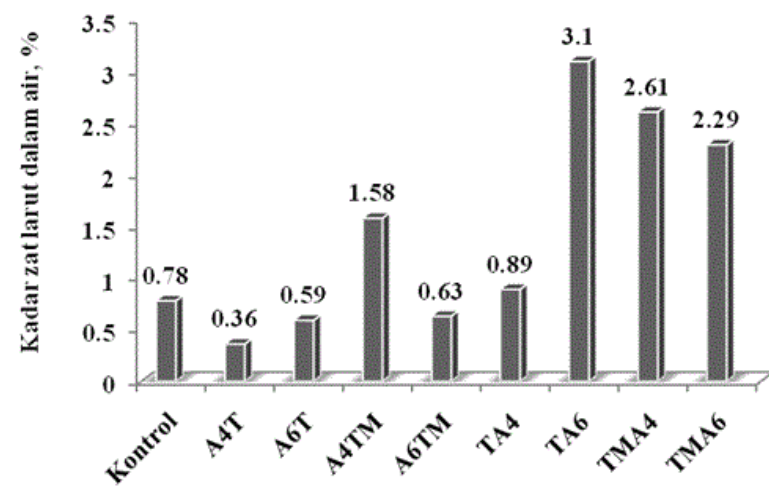

Gambar 3. Grafik histogram kadar zat larut dalam air. dah adalah $0,36 \%$ dicapai oleh perlakuan penyamakan menggunakan larutan ekstrak Tingi yang diawali dengan penambahan alum $6 \%$ (A4T). Kadar zat larut dalam air perlakuan kontrol adalah $0,78 \%$. Kadar zat larut dalam air untuk semua perlakuan memenuhi persyaratan Ethiopian Standard ES 1185: 2005, Leather - Lining leather-Specification, yang mempersyaratkan maksimum $10 \%$. Dilihat dari kandungan zat larut dalam air yang relatif kecil disebabkan karena tanin Tingi termasuk kelas condensed tannin yang mempunyai beberapa keuntungan diantaranya mudah larut dan mempunyai bahan tak larut yang kecil. pH

Pada Gambar 4 terlihat bahwa $\mathrm{pH}$ tertinggi adalah 4,63 dicapai oleh perlakuan penyamakan menggunakan larutan ekstrak Tingi dengan kombinasi mimosa dan diikuti penambahan alum 6\% (TMA6). $\mathrm{pH}$ terendah adalah 4,28 dicapai oleh perlakuan penyamakan menggunakan larutan ekstrak Tingi diikuti penambahan alum 4\% (TA4) dan perlakuan kontrol sebesar 4,28. Semua perlakuan TA4, TA6, TMA4, TMA6, A4T,A6T, A4TM, A6TM dan kontrol menunjukkan bahwa pH memenuhi persyaratan Ethiopian Standard ES 1185: 2005, Leather-Lining leather-Specification yaitu maksimum 7 .

\section{Derajat penyamakan}

Derajat penyamakan adalah ratio antara kadar tanin yang terikat dan kadar zat kulit mentah dan digunakan untuk menentukan kualitas kulit yang terkait dengan tingkat kemasakan kulit, sehingga derajat penyamakan dipengaruhi oleh kadar tanin yang terikat dan kadar zat kulit mentah.

Pada Gambar 5 dapat dilihat bahwa derajat penyamakan hasil penelitian dalam kisaran $73,18-96,37 \%$ dan semua perlakuan memenuhi persyaratan Ethiopian Standard ES 1185:2005, Leather-Lining leather-Specification, yang mem-

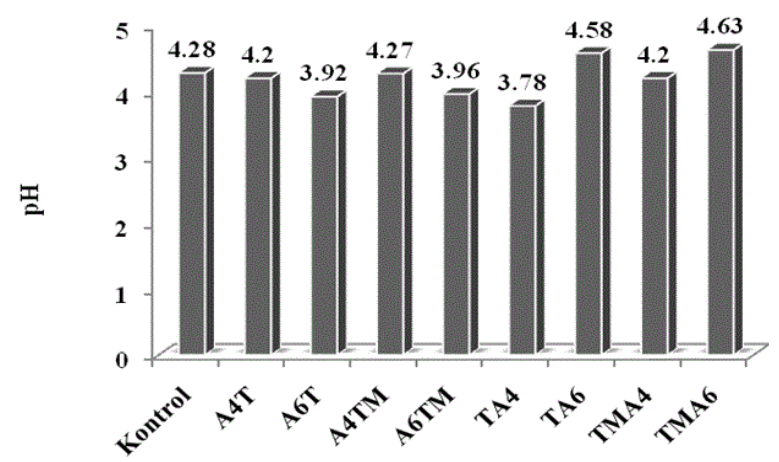

Gambar 4. Grafik histogram $\mathrm{pH}$. 


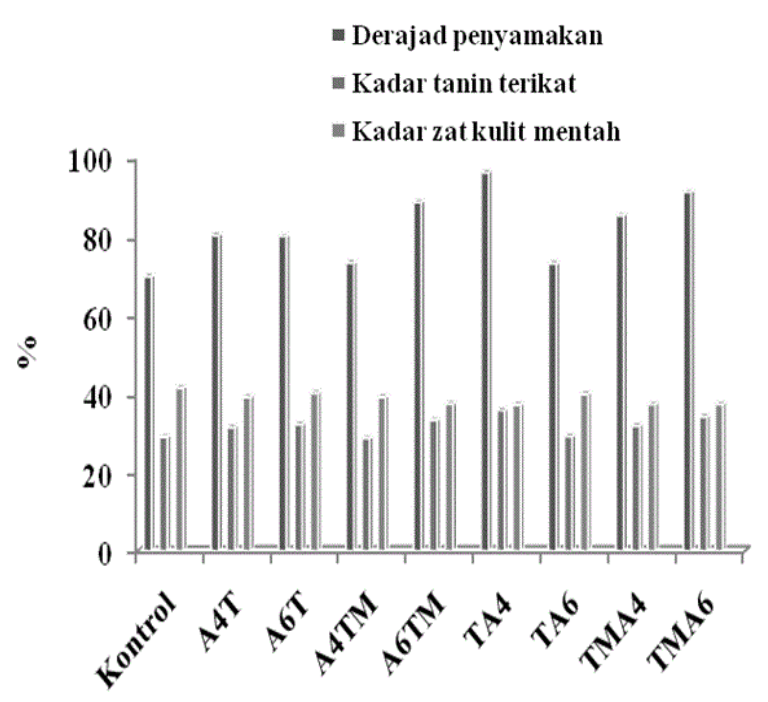

Gambar 5. Derajat penyamakan vs kadar tanin terikat dan kadar zat kulit mentah.

persyaratkan minimal $50 \%$. Derajat penyamakan tertinggi dicapai oleh perlakuan penyamakan menggunakan larutan ekstrak Tingi yang diikuti penambahan alum 4\% (TA4). Sedangkan derajat penyamakan terendah dicapai oleh perlakuan penyamakan menggunakan larutan ekstrak Tingi diikuti penambahan alum 6\% (TA6). Derajat penyamakan perlakuan kontrol adalah $69,89 \%$.

Penambahan alum dapat menaikkan derajat penyamakan baik sebelum maupun setelah penggunaan larutan ekstrak Tingi. Penambahan alum sudah cukup efektif dengan konsentrasi $4 \%$, baik pada penambahan alum yang dilakukan sebelum maupun setelah penambahan larutan ekstrak tingi. Kecuali untuk perlakuan dengan penambahan mimosa, pada penambahan mimosa yang dilakukan sebelum maupun setelah alum, yang efektif dengan konsentrasi 6\%. Perlakuan yang optimal adalah perlakuan penyamakan menggunakan larutan ekstrak Tingi yang diikuti penambahan alum $4 \%$ (TA4).

Peningkatan derajat penyamakan kulit tergantung dari banyaknya jumlah tanin yang terikat oleh kolagen kulit. Kadar tanin terikat dipengaruhi oleh banyaknya tanin yang dapat terdifusi ke dalam jaringan kulit. Kadar tanin terikat hasil penelitian dalam kisaran 28,7-35,85\%. Kadar tanin terikat tertinggi dicapai pada perlakuan penyamakan menggunakan larutan ekstrak Tingi yang diikuti penambahan alum 4\% (TA4). Sedangkan kadar tanin terikat terendah dicapai oleh perlakuan penyamakan menggunakan larutan ekstrak Tingi dengan kombinasi mimosa yang diawali dengan penambahan alum 4\% (A4TM).

Semakin banyak tanin yang terikat maka jumlah zat kulit mentah dalam kulit akan menurun, sehingga jumlah perbandingan tanin yang terikat dengan zat kulit mentah akan semakin besar $\mathrm{Nu}-$ graha, 1999). Hal ini dapat dilihat pada Gambar 5 yaitu perlakuan penyamakan menggunakan larutan ekstrak Tingi yang diikuti penambahan alum 4\% (TA4) kadar tanin terikat paling tinggi yaitu $35,85 \%$, namun kadar zat kulit mentah paling rendah yaitu $37,2 \%$ dan jumlah perbandingan tanin yang terikat dengan kadar zat kulit mentah (derajat penyamakan) paling tinggi yaitu 96,37\%.

Kadar zat kulit mentah adalah merupakan protein yang belum berikatan dengan tanin. Kadar zat kulit mentah hasil penelitian dalam kisaran 37,2$41,48 \%$. Kadar zat kulit mentah tertinggi dicapai pada perlakuan kontrol dan kadar zat kulit mentah terendah pada perlakuan penyamakan menggunaan larutan ekstrak Tingi yang diikuti dengan penambahan alum $4 \%$ (TA4).

\section{Hasil Uji Fisika Penyamakan}

Untuk mengetahui bahwa kulit yang disamak telah matang/masak maka perlu dilakukan uji penyamakan. Dari Tabel 6 dapat dilihat bahwa semua perlakuan: TA4, TA6, TMA4, TMA6, A4T, A6T, A4TM, A6TM dan kontrol, hasil penyamakan adalah masak. Hal ini menunjukkan bahwa kulit yang disamak telah masak dan dari hasil uji suhu kerut semua perlakuan $83-90^{\circ} \mathrm{C}$ signifikan pada kisaran suhu kerut untuk kulit samak nabati yaitu $70-85^{\circ} \mathrm{C}$ (Covington, 2009).

\section{Kekuatan tarik}

Kekuatan tarik merupakan salah satu parameter kekuatan fisik/fisis kulit tersamak. Pada Tabel 6 dapat dilihat bahwa kekuatan tarik tertinggi adalah $370,65 \mathrm{~kg} / \mathrm{cm}^{2}$ (TA4). Sedangkan kekuatan tarik terendah adalah $218,16 \mathrm{~kg} / \mathrm{cm}^{2}$ (A6T). Kekuatan tarik perlakuan kontrol adalah 344,55 $\mathrm{kg} / \mathrm{cm}^{2}$. Kekuatan tarik untuk semua perlakuan memenuhi persyaratan Ethiopian Standard ES 1185:2005, Leather-Lining leather-Specification, yang mempersyaratkan minimum $150 \mathrm{~kg} / \mathrm{cm}^{2}$. Tanin yang terikat oleh kulit pada proses penyamakan akan melapisi serat-serat kolagen yang terbelah pada saat proses pengapuran, sehingga serat-serat tersebut akan menjadi lebih kuat. Semakin banyak tanin yang terikat pada kulit menyebabkan kekuatan tarik dari kulit tersamak akan semakin 
Tabel 6. Rata-rata hasil uji penyamakan, kekuatan tarik, kemuluran, dan ketahanan gosok cat.

\begin{tabular}{|c|c|c|c|c|c|}
\hline \multirow[t]{2}{*}{ KODE } & \multirow[t]{2}{*}{ Penyamakan } & \multirow[t]{2}{*}{$\begin{array}{c}\text { Kekuatan Tarik } \\
\left(\mathrm{kg} / \mathrm{cm}^{2}\right)\end{array}$} & \multirow[t]{2}{*}{$\begin{array}{c}\text { Kemuluran } \\
(\%)\end{array}$} & \multicolumn{2}{|c|}{$\begin{array}{c}\text { Ketahanan gosok cat } \\
\text { (grey scale) }\end{array}$} \\
\hline & & & & Kering & Basah \\
\hline Kontrol & Masak & 344,88 & 35,44 & 5 & 4 \\
\hline A4T & Masak & 324,18 & 34,38 & 5 & $3 / 4$ \\
\hline A6T & Masak & 218,16 & 54,38 & 5 & 4 \\
\hline A4TM & Masak & 333,11 & 37,21 & 5 & 4 \\
\hline A6TM & Masak & 250,59 & 38,69 & 5 & 4 \\
\hline TA4 & Masak & 370,65 & 36,52 & 5 & 4 \\
\hline TA6 & Masak & 284,46 & 36,77 & 5 & 4 \\
\hline TMA4 & Masak & 266,55 & 32,46 & 5 & $3 / 4$ \\
\hline TMA6 & Masak & 236,42 & 34,28 & 5 & $3 / 4$ \\
\hline
\end{tabular}

tinggi (Nugraha, 1999). Dari hasil penelitian terbukti bahwa TA4 mempunyai kadar tanin terikat tertinggi $(35,85 \%)$ demikian juga kekuatan tarik tertinggi $\left(370,65 \mathrm{~kg} / \mathrm{cm}^{2}\right)$. Kekuatan tarik juga dipengaruhi oleh arah serat kulit, ketebalan, dan lokasi kulit (Covington, 2009).

\section{Kemuluran}

Persentase kemuluran kulit samak yang diuji menunjukkan elastisitas kulit samak. Kulit yang memiliki kemuluran tinggi memungkinkan kulit untuk tidak mudah robek atau rusak selama penggunaannya (Suparno et al., 2011). Pada Tabel 6 dapat dilihat bahwa kemuluran tertinggi adalah $54,38 \%$ (A6T). Sedangkan kemuluran terendah adalah 32,46\% (TMA4). Kemuluran perlakuan kontrol adalah 35,44\%. Kemuluran untuk semua perlakuan memenuhi persyaratan Ethiopian Standard ES 1185: 2005, Leather - Lining leatherSpecification, yang mempersyaratkan maksimum $70 \%$.

\section{Ketahanan gosok cat}

Pada penelitian ini tidak dilakukan proses pewarnaan, warna yang dihasilkan timbul karena warna dari bahan penyamak Tingi yaitu coklat kemerah-merahan. Dari hasil uji ketahanan gosok cat yang disajikan pada Tabel 6 menunjukkan bahwa semua perlakuan memenuhi persyaratan bahkan secara umum nilainya di atas persyaratan Ethiopian Standard ES 1185:2005, Leather-Lining leather-Specification, yang mempersyaratkan ketahanan gosok cat (kering) minimum 4 dan (basah) minimum 3. Hal ini menunjukkan bahwa tanin telah terikat kuat pada serat kulit, sehingga warna yang dihasilkan tidak luntur.

\section{Hasil Uji SEM}

Berdasarkan hasil uji kadar tanin terikat yang telah disebutkan dimuka, dari 8 (delapan) perlakuan dapat diambil kesimpulan bahwa nilai tertinggi adalah TA4, disusul TMA6, A6TM dan A6T. Oleh karena itu sampel tersebut yang akan kami analisa menggunakan SEM (Scanning Electron Microscopic).

Analisa Scanning Electron Microscopic untuk mengamati karakteristik grain dan struktur jaringan kulit tersamak. Hasil analisa SEM dari kulit hasil penelitian ditunjukkan pada Gambar 6a sampai dengan Gambar 6e. Gambar 6a merupakan sampel kulit kontrol (disamak menggunakan larutan ekstrak Tingi tanpa penambahan alum), terlihat jelas rongga kosong diantara struktur jaringan kulit tersamak.

Hasil SEM perlakuan TA4, TMA6, A6TM, A6T dibandingkan dengan kontrol tampak bersih, permukaan grain dan struktur jaringan kulit nampak lebih rata. Hal ini disebabkan karena terjadinya interaksi tanin dan non tanin dengan alum yang dapat menaikkan fiksasi dan penetrasi bahan penyamak nabati (tanin) kedalam jaringan kulit (Musa et al., 2011). Selanjutnya dalam mekanisme penyamakan semi metal, ion alum akan membentuk kompleks dengan molekul tanin yang sudah terikat dan membentuk ikatan kovalen dengan gugus karboksil kolagen (Duki et al., 2013).

Dari pengamatan hasil SEM antara TA4, TMA6, A6TM, A6T terlihat bahwa hasil SEM TA4 (Gambar 6b), struktur jaringan kulit nampak lebih kompak mengindikasikan proses penyamakan menggunakan Tingi diikuti alum 4\% akan 

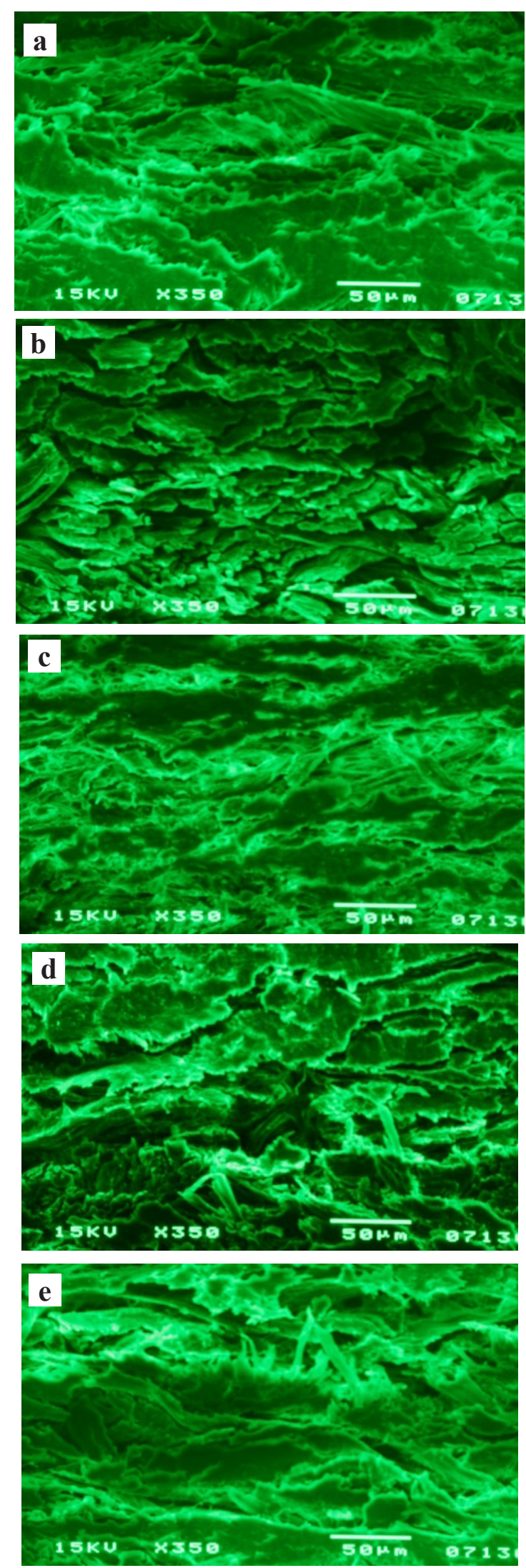

Gambar 6. Scanning electron micrograph (a) kontrol, (b) TA4, (c) TMA6, (d) A6TM dan (e) A6T dengan perbesaran $350 \mathrm{X}$. membentuk ikatan silang dengan kolagen lebih kuat dibanding perlakuan dengan penambahan mimosa 5\% dan alum 6\% (TMA6), Gambar 6(c). Demikian pula bila dibandingkan dengan perlakuan penambahan alum sebelumnya (A6TM dan A6T) yaitu pada Gambar 6(d) dan 6(e). Peningkatan ikatan silang berdampak pada tingginya kadar tanin yang terikat pada jaringan kulit, juga terhadap sifat-sifat kulit tersamak yang dihasilkan. Kadar tanin terikat paling tinggi adalah TA4 yaitu sebesar: 35,85\%, berturut-turut diikuti TMA6 dengan kadar tanin terikat: $34,18 \%$, A6TM: $33,25 \%$, dan A6T: $32,22 \%$.

Interaksi tanin dan non tanin dengan penambahan alum $4 \%$ setelah penyamakan menggunakan Tingi dapat meningkatkan fiksasi dan penetrasi tanin ke dalam jaringan kulit dan ikatan silang dengan kolagen lebih baik. Ketika konsentrasi alum dinaikkan menjadi $6 \%$ baik setelah maupun sebelum penyamakan menggunakan Tingi kadar tanin terikat menurun karena konsentrasi saturasi telah tercapai.

\section{KESIMPULAN}

Kulit kayu Tingi dapat dimanfaatkan sebagai bahan penyamak nabati dan efektif untuk digunakan sebagai bahan penyamak nabati dengan menambahkan alum. Perlakuan yang optimal adalah TA4 (Penggunaan bahan penyamak Tingi diikuti penambahan alum 4\%) dengan hasil sebagai berikut: suhu kerut $86^{\circ} \mathrm{C}$; kadar abu jumlah $0,73 \%$; kadar zat larut dalam air $0,89 \%$; $\mathrm{pH}$ 3,78 ; derajat penyamakan $96,37 \%$; penyamakan masak; kekuat-an tarik $370,65 \mathrm{~kg} / \mathrm{cm}^{2}$; kemuluran $36,52 \%$; ketahanan gosok cat nilai 5 (kering) dan 4 (basah) dan memenuhi persyaratan Ethiopian Standard ES 1185: 2005, Leather-Lining leatherSpecification. Hasil SEM (Scanning Electron Microscopic) menunjukkan bahwa penggunaan alum pada penyamakan menggunakan tanin Tingi dapat menaikkan fiksasi dan penetrasi bahan penyamak nabati (tanin) kedalam jaringan kulit.

\section{UCAPAN TERIMA KASIH}

Penulis mengucapkan terima kasih kepada semua fihak yang telah membantu dalam pelaksanaan penelitian ini.

\section{DAFTAR PUSTAKA}

Ali, S. B., Haroun, H. E., \& Musa, A. E. (2013a). Haraz bark powder extract for manufacture of nappa upper leather as alternative retanning agent. 
Journal of Forest Products \& Industries, 2(5), 2529.

Ali, S. B., Haroun, H. E., \& Musa, A. E.(2013b). Alternative combination tanning system based on haraz and aluminium for high stability leather. Journal of Forest Products \& Industries, 2(6), 2633.

Bharudin, M. A., Zakaria, S., \& Chia, C. H. (2013). Condensed tannins from acacia mangium bark: Characterization by spot tests and FTIR. The 2013 UKM FST Postgraduate Colloquium: Proceedings of the Universiti Kebangsaan Malaysia, Faculty of Science and Technology 2013 Postgraduate Colloquium, 1571(1), 153-157.

Chupin, L., Motillon, C., Charrier-El Bouhtoury, F., Pizzi, A., \& Charrier, B. (2013). Characterization of maritime pine (Pinus pinaster) bark tannins extracted under different conditions by spectroscopic methods, FTIR and HPLC. Industrial Crops and Products, 49, 897-903.

Covington, A. D., \& Covington, T. (2009). Tanning chemistry: The science of leather. Cambridge, Inggris: Royal Society of Chemistry Publishing.

Danarto, Y. C., Stefanus, A. P., \& Zery, A. P. (2011). Pemanfaatan tanin dari kulit bakau sebagai penggantigugus fenol pada resin fenol formaldehid. Dalam Prosiding Seminar Nasional Teknik Kimia: Kejuangan Pengembangan Teknologi Kimia untuk Pengolahan Sumber Daya Alam Indonesia. Yogyakarta, Indonesia: UPN Veteran.

Duki, A., Antunes, A.P.M., Covington, A.D., \& GuthrieStrachan, J. (2013). The stability of tanned and semi-metal tanned collagen in XXXII Congress of IULTCS 2013. Istambul, Turkey: IULTC.

Roberts, M. T., \& Etherington, D. (1982). Bookbinding and the conservation of books. A dictionary of descriptive terminology. Washington D.C., USA: US Government Printing Office.

Ethiopian Standard Agency. (2005). Ethiopian Standard ES 1185:2005 Leather- Lining leather Specification. Addis Ababa, Etiopia: Ethiopian Standard Agency.

Haroun, M., Khirstova, P., \& Covington, T. (2013a). Evaluation of vegetable tannin contents and polyphenols of some indigenous and exotic woody plant species in Sudan. Journal of Forest Products \& Industries, 2(4), 48-54.
Haroun, M., Khirstova, P., \& Covington, T. (2013b). Analysis of commercial vegetable tannin materials and related polyphenols of selected acacia species in Sudan. Journal of Forest Products \& Industries, 2(1), 21-28.

Kasmudjiastuti, E. (2014). Karakterisasi kulit kayu Tingi (Ceriops tagal) sebagai bahan penyamak nabati. Majalah Kulit, Karet dan Plastik, 30(2), 71-77.

Mekonnen, D., Habtamu, S., Sathiyamoorthy, M., \& Selvi, V. (2013). Preparation of eco-friendly leather by process modifications to make pollution free tanneries. Journal of Engineering Computers \& Applied Sciences, 2(5), 17-22.

Musa, A.E., Aravindhan, R., Madhan, B., Rao,R. J., \& Chandra ,S.B. (2011). Henna-Aluminium combination tannage: A greener alternative tanning system. Journal of the American Leather Chemists'Association, 106(5), 190-198.

Musa, A. E., \& Gasmelseed, G. A. (2012). Characterization of Lawsonia inermis (Henna) as vegetable tanning material. Journal of Forest Products \& Industries, 1(2), 35-35.

Nugraha, G. (1999). Pemanfaatan tanin dari kulit kayu akasia (Acacia mangium Willd) sebagai bahan penyamak nabati (Skripsi). Institut Pertanian Bogor, Indonesia.

Rusila, N. Y., Khazali, M., \& Suryadipura, I. (2012). Panduan pengenalan mangrove di Indonesia, Bogor, Indonesia: Ditjen PHKA.

Suparno, O., Kartika, I. A., \& Mubarak, S. (2011). An innovative new application of oxidizing agent to accelerate chamois leather tanning: Part I: the effects of oxidizing agents on chamois leather quality. Journal of the American Leather Chemists ' Association, 106(12), 360-366.

Ucar, M. B., Ucar, G., Pizzi, A., \& Gonultas, O. (2013). Characterization of Pinus brutia bark tannin by MALDI-TOF MS and $13 \mathrm{C}$ NMR. Industrial Crops and Products, 49, 697-704.

Vieira, M. C., Lelis, R. C. C., da Silva, B. C., \& Oliveira, G. D. L. (2011). Tannin extraction from the bark of Pinus oocarpa var. oocarpa with sodium carbonate and sodium bisulfite. Floresta e Ambiente, 18(1), $1-8$. 